Jurnal Penelitian, Vol. 10, No. 2, Agustus 2016

\title{
IMPLEMENTASI MANAJEMEN MUTU TERPADU (STUDI TRANSFORMATIF PADA PERGURUAN TINGGI)
}

\author{
Buyung Syukron
}

Sekolah Tinggi Agama Islam Negeri Jurai Siwo Metro

buyungsyukron@gmail.com

\begin{abstract}
The system of quality management implemented with the consistent commitment would provide the benefits and success for all stakeholders in the University. To obtain those benefits and success should be based on several principles of the established quality management. The starting entry of foreign University enliven the "competition" existed in Indonesia. The University is not only seen as the center of science, research, and community service, but also as the corporation entity of "producing science" that needs to compete to ensure the survival. The competition, as experienced by companies for profit, covers the competition of quality, price, and service. University as nonprofit entity also faces the same case. To manage these all, it needs the knowledge and skill of management namely integrated quality management of University.
\end{abstract}

Keywords: Integrated Quality Management, Transformation of Management, University 


\begin{abstract}
Abstrak
Sistem manajemen mutu yang dïmplementasikan dengan komitmen yang konsisten, akan memberikan manfaat dan kesuksesan bagi semua pemangku kepentingan dalam institusi perguruan tinggi tersebut. Sebingga untuk mencapai manfaat dan kesuksesan tersebut harus dilandasi dengan beberapa prinsip manajemen mutu yang sudah ditetapkan. Mulai masuknya perguruan tinggi luar negeri memeriabkan "persaingan" yang sudah ada di dalam negeri. Perguruan tinggi tidak hanya perlu dilihat sebagai pusat ilmu pengetahuan, pusat penelitian, dan pusat pengabdian masyarakat, tetapi juga suatu entitas korporat "penghasil ilmu pengetahuan" yang perlu "bersaing" untuk menjamin kelangsungan hidup. Persaingan, sebagaimana dialami oleh perusahaan for profit, meliputi persaingan di bidang mutu, harga, dan layanan. Perguruan tinggi sebagai suatu entitas non profit, juga menghadapi hal yang sama. Untuk pengelolaan semua itu, diperlukan pengetahuan dan ketrampilan manajemen, yaitu manajemen terpadu Perguruan Tinggi.
\end{abstract}

Kata Kunci: Manajemen Mutu Terpadu, Transformasi Manajemen, Perguruan Tinggi

\title{
A. Pendahuluan
}

Ilmu manajemen berkembang terus hingga saat ini. Ilmu manajemen memberikan pemahaman kepada kita tentang pendekatan ataupun tata cara penting dalam meneliti, menganalisis dan memecahkan masalah-masalah yang berkaitan dengan manajerial. Yang dapat diartikan sebagai ilmu dan seni tentang upaya untuk memanfaatkan semua sumber daya yang dimiliki untuk mencapai tujuan secara efektif dan efesien. Perkembangan ilmu manajemen yang semakin pesat melahirkan sebuah sistem manajemen yang baik. Dalam rangka menunjang kemajuan perkembangan sistem perguruan tinggi yang baik, penerapan sistem manajemen mutu perguruan tinggi menurut Firdaus sangatlah dibutuhkan, untuk menjamin terlaksananya perbaikan mutu perguruan tinggi secara berkelanjutan. Agar penerapan prinsip manajemen mutu dalam suatu institusi perguruan tinggi menjamin terlaksananya perbaikan 
mutu secara berkelanjutan. Institusi harus menyusun sistem mutu dalam bentuk pedoman mutu (Quality Manual), tertulis sebagai acuan bagi semua orang yang terlibat dalam pencapaian standar-standar kinerja mutu yang ditetapkan. Implementasi sistem manajemen mutu harus diaudit secara berkala dalam rangka memperoleh masukan untuk manajemen review untuk penyempurnaan sistem itu sendiri. Di Indonesia pendidikan tinggi mengalami perbahan panorama selama dekade terakhir. Perubahan panorama yang dimaksud meliputi perubahan paradigma, pengelolaan, persaingan dan sebagainya.

Perubahan paradigmaterutamadipicuoleh perkembangan teknologi informasi, sehingga e-learning, e-university, dan sejenisnya mulai banyak dibicarakan dan diusahakan. Begitu juga dengan perubahan pengelolaan menyangkut badan penyelenggaraan pendidikan tinggi, baik yang diselenggarakan pemerintah maupun swasta. Perguruan tinggi tidak hanya perlu dilihat sebagai pusat ilmu pengetahuan, pusat penelitian, dan pusat pengabdian kepada masyarakat, tetapi juga suatu entitas korporat "penghasil ilmu pengetahuan" yang perlu "bersaing" untuk menjamin kelangsungan hidup. Persaingan, sebagaimana dialami oleh perusahaan profit, meliputi persaingan di bidang mutu, harga, dan layanan. Perguruan tinggi sebagai suatu entitas non profit, menghadapi hal yang sama pula. Pengelolaan semuanya memerlukan pengetahuan dan ketrampilan manajemen, yaitu manajemen perguruan tinggi.

Pendidikan Tinggi dan Perguruan Tinggi, istilahnya sering saling dipertukarkan dengan anggapan mempunyai arti sama, sedangkan sebenarnya mempunyai arti yang berlainan. Pendidikan tinggi adalah pendidikan pada jalur pendidikan sekolah pada jenjang yang lebih tinggi daripada pendidikan menengah di jalur pendidikan sekolah. Sebaliknya, perguruan tinggi adalah satuan pendidikan yang menyelenggarakan pendidikan tinggi.

Tujuan pendidikan tinggi menurut Peraturan Pemerintah RI Nomor 60 Tahun 1999 adalah sebagai berikut: 
1. Menyiapkan peserta didik menjadi anggota masyarakat yang memiliki kemampuan akademik dan atau profesional yang dapat menerapkan, mengembangkan dan atau memperkaya khasanah ilmu pengetahuan, teknologi dan atau kesenian.

2. Mengembangkan dan menyebarluaskan ilmu pengetahuan, teknologi, dan atau kesenian serta mengupayakan penggunaannya untuk meningkatkan taraf kehidupan masyarakat dan memperkaya kebudayaan nasional.

Pendidikan tinggi terdiri atas pendidikan akademik dan pendidikan profesional. Pendidikan akademik merupakan pendidikan yang diarahkan, terutama pada penguasaan ilmu pengetahuan, sedangkan pendidikan profesional merupakan pendidikan yang diarahkan terutama pada kesiapan penerapan keahlian tertentu.

Perguruan tinggi menyelenggarakan pendidikan tinggi, penelitian, serta pengabdian kepada masyarakat. Perguruan tinggi merupakan kegiatan dalam upaya menghasilkan manusia terdidik. Penelitian merupakan kegiatan telaah taat kaidah dalam upaya menemukan kebenaran dan atau menyelesaikan masalah dalam ilmu pengetahuan, teknologi, dan atau kesenian. Pengabdian kepada masyarakat merupakan kegiatan yang memanfaatkan ilmu pengetahuan dalam upaya memberikan sumbangan demi kemajuan masyarakat. Perguruan Tinggi dapat berbentuk Akademik, Politeknik, Sekolah Tinggi, Institut atau Universitas.

Tulisan ini akan mencoba membahasa secara komprehensif tentang sistem sekaligus prinsip-prinsip manajemen yang dapat diimplementasikan pada sebuah perguruan tinggi dalam upaya mencapai kualitas pendidikan yang berkelanjutan.

\section{B. Pembahasan}

\section{Dimensi Makna Perguruan Tinggi}

Sebelum membicarakan manajemen perguruan tinggi, lebih dahulu perlu ditelaah mengenai hakekat yang lebih utuh 
mengenai perguruan tinggi, karena entitas perguruan tinggi mempunyai beberapa dimensi fungsi atau dimensi makna. Perguruan tinggi adalah suatu satuan pendidikan penyelenggara pendidikan tinggi. Tujuan pendidikan tinggi ialah penguasaan ilmu pengetahuan dan teknologi. Penggunaan ilmu pengetahuan dan teknologi tersebut untuk peningkatan taraf kehidupan masyarakat. Dengan demikian, ada sekurang-kurangnya empat atau lima dimensi makna yang melekat pada perguruan tinggi, yaitu (a) dimensi keilmuan (ilmu dan teknologi), (b) dimensi pendidikan (pendidikan tinggi), (c) dimensi sosial (kehidupan masyarakat), dan (d) dimensi korporasi (satuan pendidikan/ penyelenggara).

Di atas semua itu, apabila pendidikan tinggi dimaksudkan untuk meningkatkan martabat manusia, dapat diangkat ke dalam dimensi makna yang lebih mendalam, yaitu (e) dimensi etis.

Dalam pembicaraan manajemen perguruan tinggi, berbagai dimensi makna itulah antara lain yang membedakannya dengan manajemen perusahaan atau manajemen entitas lain. Oleh karena itu, sebelum membicarakan mengenai manajemen perguruan tinggi, ada baiknya kelima dimensi makna tersebut ditelaah satu persatu.

\section{a. Dimensi Eis}

Perguruan Tinggi dikenal sebagai pusat kreatifitas dan pusat penyebaran ilmu pengetahuan bukan demi kreativitas itu sendiri, tetapi demi kesejahteraan umat manusia. Hakekat tugas dan panggilan Perguruan Tinggi ialah mengabdikan diri pada penelitian, pengajaran dan pendidikan para mahasiswa yang dengan sukarela bergabung dengan para dosen dalam cinta yang sama akan pengetahuan. Makna ini akan menjamin bahwa penemuan baru itu digunakan untuk kesejahteraan otentik individu dan masyarakat secara keseluruhan. Di sini terasa kekentalan dimensi moral dan etis penemuan ilmu pengetahuan dan teknologi. Peran Perguruan Tinggi pada perlindungan martabat manusia, pada tanggung jawab moral penemuan ilmu pengetahuan dan teknologi, adalah beberapa contoh dimensi etis dari makna perguruan tinggi. 


\section{b. Dimensi Keilmuan}

Dunia perguruan tinggi adalah dunia ilmu pengetahuan. Tujuan utama pendidikan tinggi adalah mengembangkan dan menyebarkan ilmu pengetahuan, teknologi dan kebudayaan dengan proses belajar mengajar, penelitian dan pengabdian kepada masyarakat. Hanya di perguruan tinggi, melalui pendidikan tinggi, ilmu pengetahuan betul-betul dikembangkan, dan bukan di pendidikan yang lebih rendah atau di tempat lain.

c. Dimensi Pendidikan

Pendidikan tinggi adalah pendidikan, yaitu pendidikan pada tingkat tinggi. Tetapi hal ini sering menimbulkan polemik, apakah memang betul bahwa proses yang terjadi di universitas itu suatu pendidikan, atau suatu pembelajaran, karena arti 'pendidikan' lain sama sekali dengan 'pembelajaran'. Namun polemik ini mungkin dapat didamaikan dengan penjelasan bahwa di dalam perguruan tinggi, terjadi pendidikan melalui pembelajaran. Pendidikan dapat diberikan baik dalam kurikulum intra, kurikulum ekstra, maupun kurikulum tersembunyi. Dalam kurikulum intra, pendidikan dapat diberikan dalam bentuk penjelasan dan contoh-contoh aplikasi ilmu pengetahuan, dalam kurikulum ekstra, pendidikan dapat diberikan dalam seni budaya, seni olahraga, seni organisasi, dan sebagainya. Dalam kurikulum tersembunyi, pendidikan dapat diberikan dalam contoh nyata pengaturan dan pengelolaan perguruan tinggi. Disiplin, keterbukaan, pelayanan, bantuan pada yang lemah, kejujuran, kerja keras, dan sebagainya yang diperlihatkan dalam pengelolaan perguruan tinggi adalah nilai-nilai konkrit yang dapat merupakan contoh nyata untuk pendidikan.

\section{d. Dimensi Sosial}

Penemuan ilmiah dan penemuan teknologi telah menciptakan pertumbuhan ekonomi dan industri yang sangat besar. Melalui pertumbuhan ekonomi dan industri ini, kesejahteraan manusia juga ditingkatkan. Melalui kegiatan dan perjuangan para ahli dan mahasiswa, kehidupan demokrasi ditingkatkan dan martabat manusia lebih dihargai. Perguruan tinggi mempersiapkan para mahasiswa untuk mengambil tanggung jawab di dalam masyarakat. 


\section{e. Dimensi Korporasi}

Perguruan Tinggi memberikan jasa kepada masyarakat berupa pendidikan tinggi, dalam bentuk proses belajar mengajar, dan penelitian. Yang diajarkan dan diteliti adalah mengenai ilmu pengetahuan. Jadi bisnis pendidikan tinggi ialah ilmu pengetahuan. Perguruan tinggi mempunyai pelanggan, yaitu para mahasiswa dan masyarakat pengguna lulusannya. Perguruan tinggi menghadapi persaingan yaitu antar perguruan tinggi lain, baik dari dalam negeri maupun dari luar negeri.

Ada semacam break even point (BEP) yang harus dicapai, dalam penyelenggaraan perguruan tinggi. Perguruan tinggi memiliki dan mengelola berbagai sumber daya seperti manusia, barang-barang, peralatan, keuangan, dan metode. Perguruan tinggi perlu memperkenalkan produknya pada masyarakat, agar dikenal dan 'dibeli'. Semua hal tersebut menunjukkan kesamaan antara perguruan tinggi dengan perusahaan. Inilah dimensi korporasi perguruan tinggi.

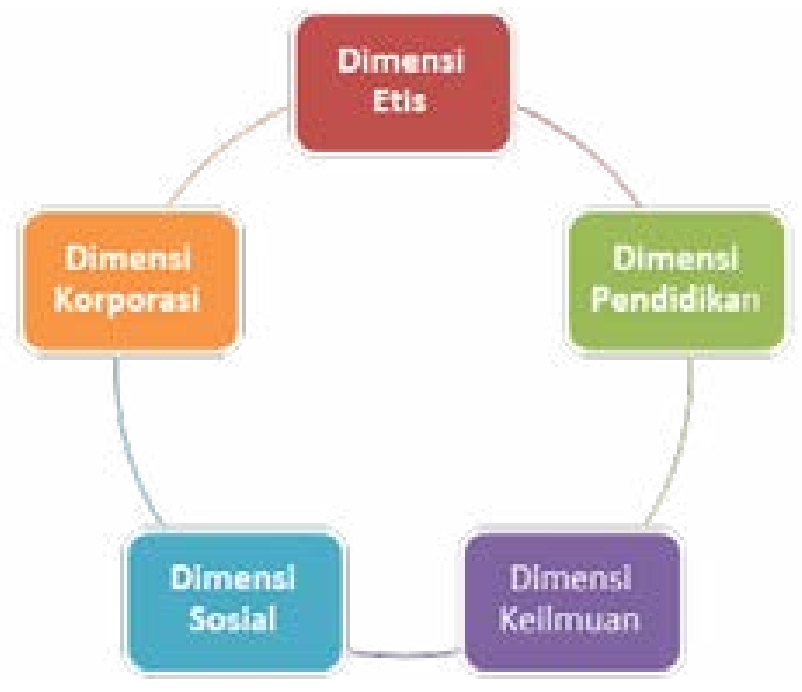

Gambar 1. Lima Dimensi Perguruan Tinggi 


\section{Manajemen pada Organisasi Nirlaba}

Dalam Undang-Undang RI Nomor 16 Tahun 2001 Tentang Yayasan misalnya, Yayasan di sebut sebagai badan hukum yang harus mempunyai maksud dan tujuan sosial, keagamaan, dan kemanusiaan. ${ }^{1}$ Dalam Peraturan Pemerintah Nomor 61 Tahun 1999 Tentang Penetapan Perguruan Tinggi Negeri Sebagai Badan Hukum, digunakan istilah 'nirlaba'.' Selanjutnya dalam Peraturan Pemerintah Nomor 60 Tahun 1999 Tentang Pendidikan Tinggi, disebutkan bahwa penyelenggaraan pendidikan tinggi yang dilakuan oleh masyarakat haruslah berbentuk yayasan atau badan yang bersifat 'sosial'. Jadi dalam praktek, agaknya Istilah 'nirlaba' dan 'sosial' digunakan dengan maksud dan arti yang sama.

Dari definisi manajemen yang sudah disampaikan di atas, terlihat bahwa organisasi sosial atau nirlaba juga memerlukan manajemen, karena di dalamnya ada sejumlah sumber daya yang harus digunakan untuk tujuan tertentu dengan melalui proses perencanaan, pengorganisasian, penggerakan, dan pengawasan. Organisasi sosial atau nirlaba menghadapi juga keterbatasan sumber daya, memerlukan juga marketing, seringkali menghadapi persaingan, memerlukan efisiensi dan efektivitas kerja, dan sebagainya seperti perusahaan biasa.

Organisasi sosial atau nirlaba seringkali dihadapkan pada kenaikan biaya terus menerus, penerimaan sumbangan dan donasi yang relatif makin mengecil, dan kompetisi organisasi perusahaan yang masuk bidang sosial. Untuk itu mereka seringkali terpaksa mencari pemecahan dengan melakukan usaha lain yang mendatangkan pendapatan untuk menunjang kegiatan utamanya, yaitu kegiatan sosial. Oleh karena itu, sering kali suatu organisasi sosial harus mengelola beberapa kegiatan yang bersifat campuran, yaitu kegiatan sosial dan kegiatan usaha yang mendatangkan keuntungan. Disini dibutuhkan

${ }^{1}$ Tambahan Lembaran Negara RI No. 4132, Undang-Undang Republik Indonesia No. 16 Tabun 2001 Tentang Yayasan, (Jakarta: t.p., 2001), hlm. 7.

${ }^{2}$ Tambahan Lembaran Negara RI No. 3860, Peraturan Pemerintab Republik Indonesia, No. 61 Tahun 1999 Tentang Penetapan Perguruan Tinggi Negeri Sebagai Badan Hukum, (Jakarta: t.p., 1999), hlm. 8. 
manajemen untuk usaha yang mendatangkan keuntungan dan manajemen untuk usaha sosial. Disini diperlukan ketrampilan manajemen untuk mencegah jangan sampai usaha bisnis yang mendatangkan keuntungan tersebut justru menenggelamkan usaha sosial utamanya.

Hal di atas memberikan justifikasi dan anggapan bahwa kegiatan sosial atau nirlaba harus dikelola dengan lebih baik, dengan cara dan sistem yang lebih menjamin efisiensi dan efektivitas, dengan cara-cara yang lebih modern dan teruji. Untuk itu diperlukan manajemen kegiatan sosial atau nirlaba. Hanya sayangnya, literatur khusus mengenai manajemen kegiatan nirlaba jumlahnya sangat terbatas, tidak sebanding dengan jumlah literatur di bidang manajemen bisnis. Namun sebetulnya sebagian besar prinsip-prinsip manajemen kegiatan bisnis berlaku pula untuk manajemen kegiatan nirlaba.

\section{Manajemen Perguruan Tinggi Modern}

Pengertian manajemen atau seringkali disebut pula "pengelolaan" merupakan kata yang digunakan sehari-hari, sehingga diandaikan semua orang tahu artinya. Definisi sesungguhnya kata tersebut ternyata banyak sekali, tergantung pada cara pandang, kepercayaan, atau pengertian seseorang. ${ }^{3}$ Ada definisi yang digunakan misalnya yang dirumuskan oleh G.R. Terry, sebagai berikut: 'Management is a distinct process consisting of planning, organizing, actuating, and controlling, performed to determine and accomplish stated objectives by the use of human beings and other resources".

Dalam pengertian definisi ini, ada aktivitas yang jelas berupa proses manajemen. Selanjutnya, aktivitas dilakukan untuk mencapai tujuan tertentu dan dilakukan melalui orang lain dengan bantuan sumber daya lain pula, yang dinamakan orang dan sumber daya lain biasa disebut $5 \mathrm{M}$, yaitu men, materials, machines, methods,

${ }^{3}$ Soedijarto, Menuju Pendidikan Nasional Yang Relevan dan Bermutu, (Jakarta: Balai Pustaka, 2001), hlm. 20.

${ }^{4}$ Anupam Karmakar and Bisdisha Sarkar Datta, Principles And Practice Of Management and Business Communication, (India: Dorling Kondersley Pvt. Ltd, 2012), hlm. 5 . 
dan money. ${ }^{5}$

Ada lima aktivitas yang harus dilalui dalam proses manajemen; pertama, Perencanaan, yang meliputi perencanaan program kerja, termasuk perencanaan anggaran, bukan merupakan hal baru bagi perguruan tinggi, baik perencanaan lima tahunan maupun perencanaan tahunan. Namun, perencanaan perlu pula dilakukan untuk perencanaan strategis, yaitu perencanaan yang menentukan hidup mati dan berkembang tidaknya suatu universitas.

Kedua, Pengorganisasian, fungsi pengorganisasian termasuk fungsi pengisian staf yang sesuai untuk setiap tugas atau kedudukan. Pengisian staf atau karyawan perlu membedakan beberapa jenis karyawan yang bekerja di suatu universitas, yang masing-masing mempunyai tugas khas dan karakteristik sendirisendiri.

Ketiga, Penggerakan, Fungsi tugas penggerakan (actuating) adalah tugas menggerakkan seluruh manusia yang bekerja dalam suatu perguruan tinggi agar masing-masing bekerja sesuai yang telah ditugaskan dengan semangat dan kemampuan maksimal. Ini merupakan tantangan yang sangat besar bagi fungsi manajemen karena menyangkut manusia, yang mempunyai keyakinan, harapan, sifat, tingkat laku, emosi, kepuasan, pengembangan, dan akal budi serta menyangkut hubungan antar pribadi. Oleh karena itu, banyak yang mengatakan bahwa fungsi penggerakan adalah fungsi yang paling penting serta paling sulit dalam keseluruhan fungsi manajemen.

Keempat, Pengukuran, parameter pengukuran atau suatu alat yang seringkali digunakan untuk membantu memahami kebutuhan manusia adalah hierarki kebutuhan yang dikembangkan oleh AH Maslow. Hierarki mengenai lima tingkat (kadang-kadang dibagi menjadi enam) yakni kebutuhan dasar manusia, dari yang paling rendah sampai yang paling tinggi, sebagai berikut:

a. Kebutuhan fisiologis (physiological need)

Lapar dan haus adalah kebutuhan yang paling dasar bagi

${ }^{5}$ M. Manullang, Dasar-Dasar Manajemen Perguruan Tinggi, (Jakarta: Ghalia Indonesia, 1983), hlm. 34. 
manusia dan harus dipenuhi terlebih dahulu sebelum semua kebutuhan lainnya dipenuhi.

b. Kebutuhan keamanan (safety need)

Keamanan adalah tingkat kebutuhan kedua, yaitu berupa pakaian, tempat perlindungan atau rumah tempat tinggal, dan lingkungan yang menjamin keamanan seperti pekerjaan tetap, pensiun dan asuransi.

c. Kebutuhan afeksi (affection need)

Termasuk dalam kebutuhan tingkat tiga adalah pengakuan termasuk dalam lingkungan tertentu, bukan hanya lingkungan keluarga, tetapi juga lingkungan sosial lainnya, seperti tempat kerja.

d. Kebutuhan penghargaan (esteem need)

Kebutuhan penghargaan berbentuk kebutuhan penghargaan diri, rasa keberhasilan, dan pengakuan dari orang lain. Kebutuhan akan status merupakan dorongan utama untuk mencapai keberhasilan lebih lanjut.

f. Kebutuhan aktualisasi diri (self-actualization need)

Tingkat tertinggi kebutuhan manusia adalah rasa pemenuhan diri, yaitu sumbangan optimalnya pada sesama manusia, suatu realisasi penuh atas potensi diri manusia.

Kelima, Pengawasan, pengawasan adalah fungsi terakhir manajemen, namun bukan berarti yang paling kurang penting. Pengawasan adalah pengamatan dan pengukuran, apakah pelaksanaan dan hasil kerja sudah sesuai dengan perencanaan atau tidak. Kalau tidak, apa kendalanya dan bagaimana menghilangkan kendala agar hasil kerja dapat sesuai dengan yang diharapkan. Fungsi pengawasan tidak harus dilakukan hanya setiap akhir tahun anggaran, tetapi justru harus secara berkala dalam waktu yang lebih pendek, misalnya setiap bulan, sehingga perbaikan yang perlu dilakukan tidak terlambat dilaksanakan.

\section{Penerapan Total Quality Management}

Penerapan (implementasi) sistem manajemen mutu dalam upaya meningkatkan kualitas perguruan tinggi dilakukan melalui beberapa hal sebagaimana tabel berikut; 
Tabel 1. Implementasi Manajemen Mutu Perguruan Tinggi

\begin{tabular}{|c|c|}
\hline $\begin{array}{l}\text { Bertekad menjadi } \\
\text { PT yang bermutu }\end{array}$ & $\begin{array}{l}\text { a. Menjadi bermutu itu harus dengan niat dan } \\
\text { dilanjutkan dengan melakukan usaha yang } \\
\text { nyata ke arah itu. } \\
\text { b. Pengakuan orang lain (mahasiswa \& sejawat } \\
\text { \& mayarakat) bahwa PT kita adalah PT } \\
\text { bermutu merupakan kunci ke arah masa } \\
\text { depan yang cerah. }\end{array}$ \\
\hline Adopsi filosofi mutu & $\begin{array}{l}\text { Perguruan tinggi yang bermutu adalah yang } \\
\text { dapat memenuhi kebutuhan dan harapan } \\
\text { masyarakat. Kebutuhan masyarakat adalah } \\
\text { berkembangnya SDM bermutu dan tersedianya } \\
\text { informasi, pengetahuan dan teknologi yang } \\
\text { dapat meningkatkan taraf hidup. Sehingga } \\
\text { Perguruan tinggi yang bermutu adalah yang } \\
\text { secara keseluruhan memberi kepuasan kepada } \\
\text { masyarakat. }\end{array}$ \\
\hline
\end{tabular}

Fokus pada pelanggan a. Perhatian PT selalu dipusatkan pada kebutuhan dan harapan para pelanggannya: mahasiswa, masyarakat, industri, pemerintah, dll.

b. Tugas utama PT adalah memenuhi dan memuaskan kebutuhan dan harapan para pelanggannya. Untuk ini perguruan tinggi harus dapat: mengetahui ciri-ciri pelanggan-pelanggannya, mengidentifikasi dan menganalisa kebutuhan dan harapan pelanggan. 


\begin{tabular}{|c|c|}
\hline $\begin{array}{l}\text { Komitmen } \\
\text { mutu }\end{array}$ & $\begin{array}{l}\text { Harus ada kesadaran dan keyakinan akan } \\
\text { perlunya mutu kinerja, dan karenanya perlu } \\
\text { ada tekat dan rasa keterikatan yang kuat } \\
\text { untuk menjaga dan meningkatkan mutu kerja. } \\
\text { Pengajaran, penelitian, administrasi, dll yang tak } \\
\text { bermutu kadang-kadang sama nilainya dengan } \\
\text { tanpa kerja. Pendidikan dan penelitian yang tak } \\
\text { bermutu bisa berakibat lebih jelek dari tanpa } \\
\text { pendidikan dan penelitian. Komitmen yang } \\
\text { kuat pada mutu PT akan menggerakkan usaha } \\
\text { yang terus menerus untuk meningkatkan mutu, } \\
\text { dan tidak akan menyerah pada kendala-kendala } \\
\text { dan kesulitan-kesulitan lain yang menghadang. }\end{array}$ \\
\hline $\begin{array}{l}\text { Memperbaiki mutu } \\
\text { perguruan tinggi se- } \\
\text { cara berkelanjutan }\end{array}$ & $\begin{array}{l}\text { Tekad untuk meningkatkan mutu perguruan } \\
\text { tinggi harus dibuktikan dengan adanya usaha- } \\
\text { usaha nyata memperbaiki mutu. Tidak hanya } \\
\text { sekali memperbaiki dan selesai, tetapi sedikit } \\
\text { demi sedikit secara terus-menerus. Mutu } \\
\text { perguruan tinggi tidak ada langit-langitnya, } \\
\text { karena itu tidak mungkin meningkatkan mutu } \\
\text { sekaligus dan selesai. Setiap kali perlu ditetapkan } \\
\text { standar mutu dari sesuatu yang ingin dicapai. } \\
\text { Standar mutu tri darma dan administrasi PT ini } \\
\text { perlu ditingkatkan sedikit demi sedikit sesuai } \\
\text { dengan kemampuan yang dimiliki. }\end{array}$ \\
\hline
\end{tabular}




\begin{tabular}{|c|c|}
\hline $\begin{array}{l}\text { Keputusan berdasar- } \\
\text { kan data dan fakta }\end{array}$ & $\begin{array}{l}\text { Sebelum melakukan berbagai perbaikan } \\
\text { mutu pendidikan/pengajaran harus melewati } \\
\text { bermacam pengambilan kesimpulan, penilaian, } \\
\text { dan keputusan. Semua itu harus diambil/dibuat } \\
\text { berdasarkan fakta yang ada dan atau data yang } \\
\text { tersedia. Tanpa itu kesimpulan dan keputusan } \\
\text { itu akan mengandung kelemahan dan keraguan, } \\
\text { sehingga pelaksanaannya pun akan ragu-ragu. } \\
\text { Mengidentifikasi masalah pengajaran di kelas } \\
\text { juga perlu didasari oleh berbagai data dan fakta. }\end{array}$ \\
\hline $\begin{array}{l}\text { Program belajar } \\
\text { sambil bekerja }\end{array}$ & $\begin{array}{l}\text { Pekerjaan di PT jangan dilihat sebagai pekerjaan } \\
\text { rutin yang sama saja dari waktu ke waktu. Ini bisa } \\
\text { membosankan. Sebaliknya bila kerja akademis } \\
\text { dan administrasi itu dilihat sebagai tantangan } \\
\text { yang harus dicermati, maka selain akan selalu } \\
\text { menarik juga akan menggugah pelakunya untuk } \\
\text { mencari dan mencoba prosedur-prosedur lain } \\
\text { yang sekiranya akan lebih efektif dan lebih baik } \\
\text { mutunya. Setiap kegiatan di PT direncanakan } \\
\text { dengan baik, dilaksanakan dengan cermat, } \\
\text { dan hasilnya dievaluasi dibandingkan dengan } \\
\text { standar mutu yang ditentukan sebelumnya. }\end{array}$ \\
\hline $\begin{array}{l}\text { Alat dan teknik un- } \\
\text { tuk perbaikan mutu }\end{array}$ & $\begin{array}{l}\text { Data dan fakta yang ada dapat disajikan dengan } \\
\text { berbagai alat dan teknik untuk bisa dianalisa } \\
\text { dan disimpulkan. Flowchart, diagram tulang } \\
\text { ikan, tabel, diagram pareto, gantt chart, medan } \\
\text { gaya, histogram, afinitas, matrik, check sheet, } \\
\text { brainstorming, dan lain-lain. }\end{array}$ \\
\hline
\end{tabular}




\begin{tabular}{|c|c|}
\hline $\begin{array}{l}\text { Perbaikan proses } \\
\text { yang preventif }\end{array}$ & $\begin{array}{l}\text { Rendahnya mutu biasanya lebih banyak } \\
\text { disebabkan oleh kurang tepatnya prosedur } \\
\text { yang menghasilkan adanya proses yang tidak } \\
\text { mengeluarkan hasil seperti yang diharapkan. } \\
\text { Oleh karena itu dari waktu ke waktu prosedur } \\
\text { kerja yang digunakan di PT perlu ditinjau apakah } \\
\text { mendatangkan hasil yang diharapkan. Bila tidak } \\
\text { maka prosedur itu perlu diubah dengan yang } \\
\text { lebih baik dan sesuai. Setiap prosedur kerja } \\
\text { baru harus dicoba lebih dahulu. Kalau hasilnya } \\
\text { memuaskan baru diadopsi. Dengan begitu } \\
\text { dapat dicegah adanya kegagalan. }\end{array}$ \\
\hline $\begin{array}{l}\text { Pengakuan dan } \\
\text { penghargaan }\end{array}$ & $\begin{array}{l}\text { Bagi pengajar, mahasiswa atau pegawai } \\
\text { yang telah berusaha memperbaiki mutu } \\
\text { pendidikan/pengajaran/pekerjaannya perlu } \\
\text { diberi pengakuan dan penghargaan agar semua } \\
\text { yang bersangkutan dengan perguruan tinggi } \\
\text { itu terdorong untuk terus melakukan usaha- } \\
\text { usaha perbaikan. Dosen-dosen muda dan } \\
\text { karyawan dapat saja mencoba cara-cara kerja } \\
\text { baru dan ternyata lebih efektif. Kalau ini terjadi } \\
\text { maka seyogyanya usaha mereka itu diakui } \\
\text { dan diberi penghargaan sepantasnya. Karena } \\
\text { usaha perbaikan mutu perguruan tinggi bukan } \\
\text { monopoli pengajar dan pimpinan perguruan } \\
\text { tinggi saja. Untuk mengajak partisipasi dari } \\
\text { semua pihak, adanya system pengakuan dan } \\
\text { penghargaan ini sangat penting. }\end{array}$ \\
\hline
\end{tabular}




\begin{tabular}{|c|c|}
\hline $\begin{array}{l}\text { Perbaikan prosedur } \\
\text { antar fungsional }\end{array}$ & $\begin{array}{l}\text { Perguruan tinggi yang bermutu bukan hasil } \\
\text { karya orang secara individual, tetapi hasil } \\
\text { kerjasama beberapa orang yang bekerjasama. } \\
\text { Orang-orang yang bekerjasama itu mungkin } \\
\text { berbeda status dan fungsinya. Karena itu } \\
\text { perlu ditingkatkan prosedur-prosedur yang } \\
\text { menghasilkan kerjasama antar fungsi itu. } \\
\text { Misalnya perlu dikembangkan prosedur yang } \\
\text { lebih memudahkan kerjasama antar pengajar } \\
\text { dengan mahasiswa, dengan teknisi, laboran, } \\
\text { pustakawan, pegawai administrasi, dan dengan } \\
\text { sesama pengajar. Prosedur yang memudahkan } \\
\text { interaksi antar mereka ini perlu dikembangkan } \\
\text { dan diperbaiki. }\end{array}$ \\
\hline $\begin{array}{l}\text { Struktur yang men- } \\
\text { gundang partisipasi }\end{array}$ & $\begin{array}{l}\text { Struktur adalah cara pengaturan yang mantap, } \\
\text { yang memungkinkan sebanyak mungkin } \\
\text { orang untuk berpartisipasi memperbaiki } \\
\text { perguruan tinggi. Misalnya: rencanakan dan } \\
\text { tradisikan adanya pertemuan antar pengajar } \\
\text { dan mahasiswa untuk mereview proses belajar } \\
\text { mengajar, dan berdiskusi dalam rangka mencari } \\
\text { cara-cara yang lebih baik dan lebih efektif } \\
\text { untuk mencapai pendidikan/pengajaran yang } \\
\text { bermutu. Demikian pula pertemuan antara } \\
\text { para pengajar dengan orang tua mahasiswa, } \\
\text { alumni, para pengusaha, unsur pemerintah, } \\
\text { tokoh masyarakat, dan para donatur. }\end{array}$ \\
\hline
\end{tabular}

Sumber: Stanley J. Spanbauer, A Quality System for Education, Milwaukee: ASQC Quality Press, 1992.

Dari pemaparan di atas dapat dianalisis bahwa gerakan perbaikan mutu dalam bidang pendidikan di dunia, sebenarnya belum terlalu lama. Perintisan Total 
Quality Management (TQM) dalam bidang pendidikan diawali di Amerika Serikat pada akhir tahun 1980-an, diikuti oleh Inggris. Peningkatan perhatian baru dimulai pada tahun 1990. Demikian pula TQM sebagai mata kuliah akademik, masih sangat sedikit diterapkan. Di Inggris, sejak berlakunya 'Education Reform Act' pada tahun 1988, perhatian terhadap mutu pendidikan mulai meningkat. Undang-undang ini banyak menitikberatkan pada monitoring "performance indicators" (indikator kinerja) dari proses pendidikan. Akan tetapi indikatorindikator ini, terutama hanya merupakan pedoman untuk mengukur efisiensi mutu pembelajaran atau efektivitas institusi dalam memenuhi kebutuhan pelanggan. Jika ingin memperoleh lebih banyak apa yang ada di balik indikator kinerja tersebut, suatu institusi harus mulai lebih serius pada TQM dengan artian perbaikan berkelanjutan (continuous improvement) terhadap standar pelanggannya seiring meningkatnya persyaratan mutu pelanggan.

Peningkatan kualitas dalam perguruan tinggi tidak dapat dilihat sebagai proses yang "sekejap jadi“. Kegiatan ini merupakan sebuah proses jangka panjang yang membutuhkan perubahan organisasi dan restrukturisasi yang tidak boleh kepalang tanggung. Komitmen untuk berubah ke arah mutu yang lebih baik harus dipahami oleh semua level manajemen dan harus didasari oleh kehendak mau berubah. Hal yang lebih penting disamping kemauan mau berubah adalah kenyamanan dalam melaksanakan peran dalam proses perubahan ini. Disamping level manajer yang harus paham dan tahu tugasnya tentang perubahan ini, staf pun harus tahu komitmen dari manajer mereka. Komitmen yang dideklarasikan secara jelas akan memotivasi para staf untuk mau bersama-sama melakukan perubahan bagi organisasi mereka secara sungguh-sungguh.

Spanbauer, menyatakan bahwa kunci keberhasilan program peningkatan kualitas di sebagian besar sektor industri swasta sangat dipengaruhi oleh keterlibatan manajemen, pengambilan keputusan yang tepat, cara berpikir yang mengindahkan 
perhitungan statistik dan pengukuran, dan pengetahuan karyawan. Beberapa komponen ini juga berlaku bagi pendidikan dalam hal:

a. Meningkatkan keterlibatan fakultas dan staf dalam hal manajemen serta pengambilan keputusan di kampus.

b. Pengambilan keputusan berdasarkan kebutuhan konsumen dan mempertimbangkan data statistik yang dimiliki.

c. Meningkatkan ketrampilan kepemimpinan bagi posisi manajemen.

d. Memberikan otoritas lebih dan tanggungjawab didelegasikan.

e. Otonomi yang lebih besar kepada tiap fakultas.

f. Meningkatkan profesionalisme staf melalui pelatihanpelatihan.

g. Tehnik partisipasi yang inovatif daripada menggunakan teknik manajemen yang otokratis.

h. Komitmen berkesinambungan terhadap perbaikan kualitas, yang menekankan kepada excellence untuk semua proses.

i. Praktek pengambilan keputusan didasarkan pada kebutuhan konsumen sesuai pada item mutu yang ditetapkan

Kualitas sebuah perguruan tinggi berarti adalah kualitas keseluruhan dalam perguruan tinggi tersebut, yang mencakup manajemen dan sumber daya manusia, tujuan organisasi, pelayanan, operasional, dan sebagainya. Adapun elemen-elemen kualitas tersebut, strategi dalam mengukur kualitas serta akibat jika kualitas tersebut diabaikan.

Untuk mulai berpikir ke arah kualitas, sebuah perguruan tinggi harus:

a. Berorientasi kepada karyawan, mahasiswa dan stakeholders sebagai pusat kualitas.

b. Pimpinan puncak/manajemen harus memiliki kemauan dan komitmen terhadap perubahan ke arah kualitas yang lebih baik.

c. Mutu merupakan kesatuan total, tidak dapat dipikirkan secara terpisah. 
d. Mutu merupakan program jangka panjang, bukan instan dan harus melibatkan banyak pihak.

e. Harus mulai memikirkan penyusunan standard kualitas yang terukur bagi seluruh program, unit, fakultas, dan lain-lain.

Implementasi sistem manajemen mutu dalam mencapai perguruan tinggi yang berkualitas secara global dapat dilihat pada gambar sebagai berikut;

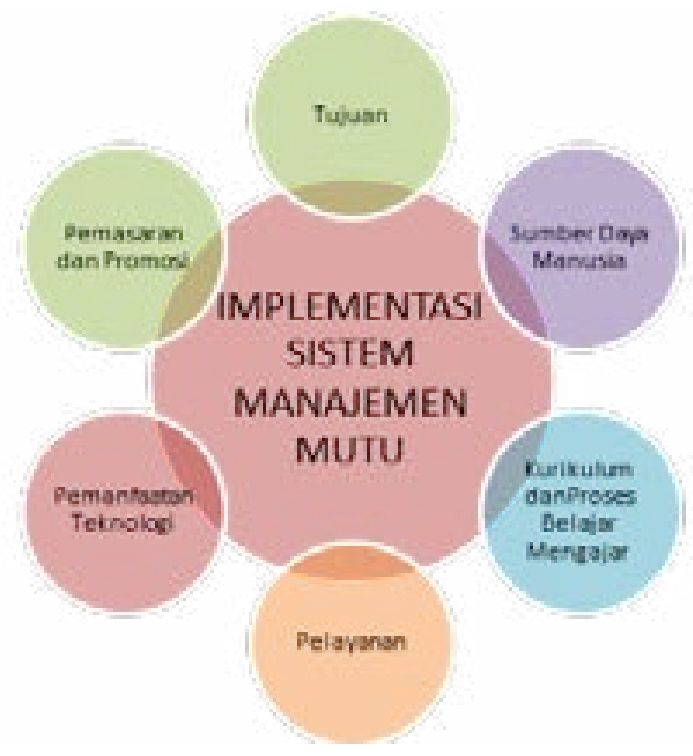

Gambar 2. Implementasi

Sistem Manajemen Mutu Pada Perguruan Tinggi

\section{Simpulan}

Tidak ada sesuatu yang tidak berubah, semua pasti akan mengalami suatu perubahan. Begitu juga dengan organisasi Pendidikan Tinggi, yang harus mampu beradaptasi dengan lingkungannya. Dibutuhkan suatu manajemen yang berkualitas dalam proses menuju sebuah perubahan, sehingga perubahan menjadi lebih terarah. Pemahaman mengenai perubahan dapat dilihat melalui perspektif manajemen mutu yang bersifat terpadu atau yang lebih dikenal dengan Total Quality Management (TQM). Solusi-solusi teoritis dan konseptual yang ditawarkan oleh 
managemen mutu terpadu diharapkan akan mampu menjawab berbagai pertanyaan-pertanyaan yang mucul dari perspektif kebutuhan akan sebuah Perguruan Tinggi yang berkualitas.

Implementasi manajemen mutu terpadu tidak menyarankan untuk menunggu sampai muncul dorongan yang kuat akan perubahan, namun kondisi organisasi Perguruan Tinggi yang selalu siap melakukan perubahan harus diciptakan. Segala penolakan dan hambatan untuk berubah harus dieliminir terlebih dahulu. Sehingga dengan begitu pemimpin perubahan akan lebih mudah menciptakan lingkungan Perguruan Tinggi yang lebih "awareness" terhadap perubahan. Bagi seorang pemimpin, "critical success factor" dapat menjadi landasan dalam mengelola Perguruan Tinggi menuju perubahan yang diharapkan. Dengan memperhatikan berbagai dimensi dalam perspektif manajemen mutu terpadu tersebut diharapkan proses perubahan menuju sebuah kesuksesan, karena pada prinsip dan hakikatnya organisasi di bentuk mengikuti tujuan dan sesuai dengan kebutuhan organisasi itu sendiri . 


\section{DAFTAR PUSTAKA}

Andrianto, Kusuma, Problematika Pendidikan di Indonesia, Jakarta: Wacana Didaktika Indonesia, 2009.

Ditjen Dikti, Pembelajaran di Perguruan Tinggi, Jakarta: Direktorat Jenderal Pendidikan Tinggi, 2000.

Gaspersz, Vincent, Manajemen Bisnis Total Dalam Era Global, Jakarta: Gramedia, 2011

Gosling, D, Supporting Learning, in Fry H, Ketteridge S and Marshall S., A Handbook for Teaching \& Learning Higher Education, UK: Kogan Page, 2009.

Knowles, Malcolm, The Modern Practice of Higher Education: a System of Management, New York: Association Press, 1970.

LN., Firdaus, Sistem Manajemen Pengelolaan Pembelajaran Bermutu di Perguruan Tinggi. Makalah disampaikan dalam "Technical Asistance Peningkatan Metode Pengajaran, Riau, 2012.

Manullang, M, Dasar-dasar Manajemen Perguruan Tinggi, Jakarta: Ghalia, 1983.

Nugroho, Rian, Public Policy, Jakarta: Elex Media Computindo, 2009.

Olivia, Peter, Developing of Management System in Higher Education, second edition, Georgia: Southern College, 1998.

Pontjorini, Ety Rochaeti- Rahayuningsih, Sistem Informasi Manajemen Pendidikan, Jakarta: Bumi Aksara, 2010.

Soedijarto, Menuju Pendidikan Nasional Yang Relevan dan Bermutu, Jakarta: Balai Pustaka, 2001.

- Pendidikan Nasional dan Pembangunan Kebudayaan dan Karakter Bangsa (Jati Diri Bangsa) dan Implikasinya terhadap Sistem Kurikulum dan Proses Pembelajaran. Makalah disampaikan Pada Sarasehan Nasional Pengembangan Pendidikan Budaya dan Karakter Bangsa, 14 Januari 2010. 
, Landasan dan Arah Pendidikan Nasional Kita, Jakarta: Kompas, 2008.

- Pendidikan Nasional sebagai Wahana Mencerdaskan Kebidupan Bangsa dan Membangun Peradaban Negara-Bangsa, Jakarta: CINAPS, 2000.

Spanbauer, Stanley J, A Quality System for Education, Milwaukee: ASQC Quality Press, 1992.

Suryad dan Tilaar, Analisis Kebijakan Pendidikan, Bandung: Remaja Rosdakarya, 1999.

Tilaar, HAR., Beberapa Agenda Reformasi Pendidikan Nasional Dalam Perspektif Abad 21, Magelang: Tera Indonesia, 1999.

Undang-Undang Republik Indonesia tentang Sistem Pendidikan Nasional Nomor 20 Tahun 2003, Jakarta: CV Eko Jaya, 2003. 